
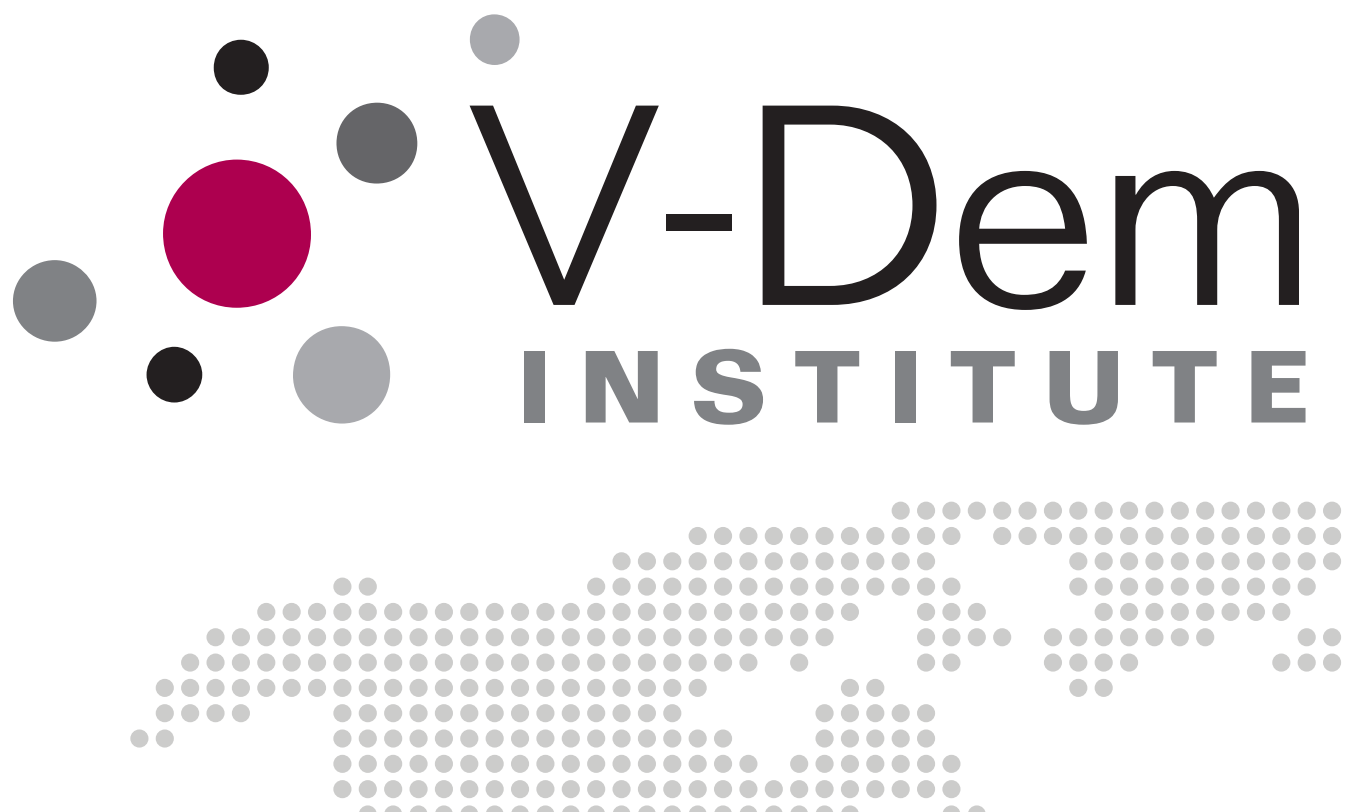
000900

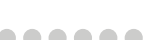
100

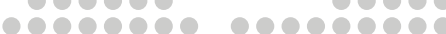

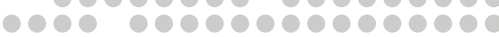

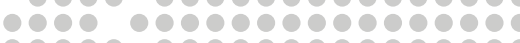

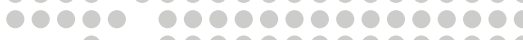
-

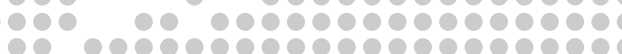

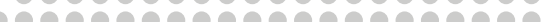

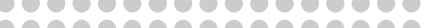
168060

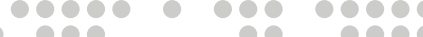

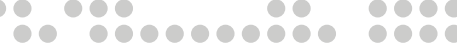

Ordinal Versions of V-Dem's Indices: For Classification, Description, Sequencing Analysis and Other Purposes

Staffan I. Lindberg

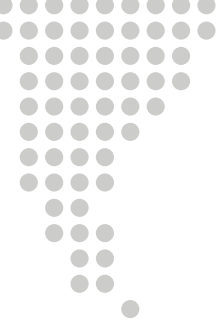

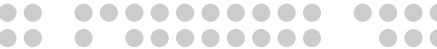

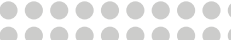
0000000000000

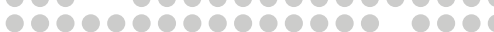

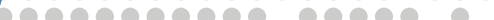

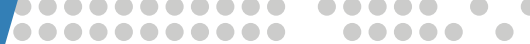

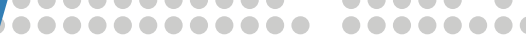

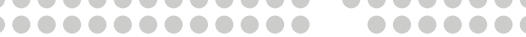

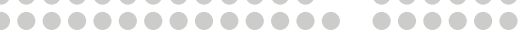
P0000000000000

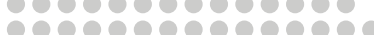
30000000000000000000 00000000000000000000 -

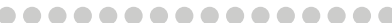

(90000000000000

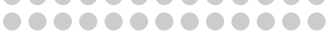

0000000000

00000000000

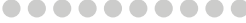

1000000000е

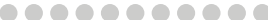

00000000000 orerererereq 0908000090 00000000

00000000 000000 000000

000000

000

100

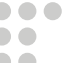

.

10

10

00

10 1 
Varieties of Democracy (V-Dem) is a new approach to the conceptualization and measurement of democracy. It is co-hosted by the University of Gothenburg and University of Notre Dame. With a V-Dem Institute at University of Gothenburg that comprises almost ten staff members, and a project team across the world with four Principal Investigators, fifteen Project Managers, 30+ Regional Managers, 170 Country Coordinators, Research Assistants, and 2,500 Country Experts, the V-Dem project is one of the largest-ever social science research-oriented data collection programs.

Please address comments and/or queries for information to:

V-Dem Institute

Department of Political Science

University of Gothenburg

Sprängkullsgatan 19, PO Box 711

SE 40530 Gothenburg

Sweden

E-mail: contact@v-dem.net

V-Dem Working Papers are available in electronic format at www.v-dem.net.

Copyright (C) 2015 by authors. All rights reserved. 


\title{
Ordinal Versions of V-Dem's Indices: \\ For Classification, Description, Sequencing Analysis and Other Purposes*
}

\author{
Staffan I. Lindberg \\ Professor, of Political Science \\ Director, V-Dem Institute \\ University of Gothenburg
}

\footnotetext{
* This research project was supported by Riksbankens Jubileumsfond, Grant M13-0559:1, PI: Staffan I. Lindberg, VDem Institute, University of Gothenburg, Sweden; by Swedish Research Council, PI: Staffan I. Lindberg, V-Dem Institute, University of Gothenburg, Sweden \& Jan Teorell, Department of Political Science, Lund University, Sweden; and by Knut \& Alice Wallenberg Foundation to Wallenberg Academy Fellow Staffan I. Lindberg, V-Dem Institute, University of Gothenburg, Sweden ; as well as by internal grants from the Vice-Chancellor's office, the Dean of the College of social Sciences, and the Department of Political Science at University of Gothenburg.
} 
Varieties of Democracy, or V-Dem for short, is approaching the conceptualization and measurement of democracy on the notions that democracy is multifaceted conceptually, and a matter of degree from a measurement perspective (Coppedge et al. 2015a, b, Lindberg et al. 2015). This is fully in line with my own position on this issue. ${ }^{1}$ For example, as a core institution of electoral democracy, multiparty elections are supposedly the only means to decide who holds legislative and executive power respectively. Yet, de jure multiparty elections take place in less than democracies too and elections, pace the political system writ large, can be characterized by varying degrees of democratic features ranging from zero to a theoretical maximum. The same reasoning can be applied to other varieties of democracy such as liberal, egalitarian, participatory, or deliberative democracy. This reasoning, which I have also pursued elsewhere, translates into viewing democracy as an attribute of the political system. ${ }^{2}$

An essentially different view is to approach democracy as an object in itself. ${ }^{3}$ For example, identification of a specific regime type conceptualized as democracy by characteristics exclusive defining for that particular regime. It would imply democracy to "be" something with object-like characteristics. Such is the logic of classical concept formation (Collier and Mahon 1993; Coppedge 2005; Munck 2001b; Sartori 1984; Schedler 2001a). For instance, it makes little sense in this approach to say that democracies are defined by political competition since competition in a broad sense is a characteristic of most political systems. The frequency of coups, insurgencies and toppling of governments is clearly indicative of the fierce competition in many authoritarian contexts. The form of political competition defining democracy would need a more precise and unambiguous specification: the struggle for the highest executive and/or legislative office is in a democracy playing out in electoral processes constituted by a particular set of rules governing candidate, party and voter eligibility criteria, political rights of speech, association and information, electoral management bodies, electoral system, district boundaries, campaign contributions, voting requirements, rules for complaints and abjuration, and so on.

It could also be argued that democracy is partly characterized by political participation of a particular kind. Political participation in democracies - as different from non-democracies - is based on the notion of citizens' political equality. Individuals, who so wish, should be able to form a political party and contest in elections on the same conditions as everyone else. All

\footnotetext{
${ }^{1}$ Unsurprisingly so perhaps, given that the present author is also one of the principal investigators of V-Dem, and Director of the V-Dem Institute.

2 Even if a political system would reach the theoretical maximum on all specified indicators of democratic attributes, it would not make democracy the object. Objectification is a matter of conceptual analysis, not empirical conclusion. If we study water and its qualities for example, finding it to be yellowish or pure does not render the color yellow or purity our object of study. For my own work in this area, see e.g. Lindberg 2006, 2009.

3 The following paragraphs build on material from Lindberg 2006, chapter 2.
} 
citizens - of age and mental sanity - should be able to cast their vote based on the principle one person, one vote. In the same way as unspecified competition is not defining for democracy, political participation in a general sense exists in most systems of rule only that it is characterized by patron-client relationships, exclusion, or other non-equal relationships. There are many examples of inadequate specifications of "democracy" as well as "authoritarianism" in the literature on democratization (e.g. Munck 1994, 2001b). Nevertheless, approaching democracy as an object, a "thing", requires a clear and unambiguous specification of the defining attributes. However, we must guard against overstating the degree to which these attributes cohere to define democracy as this leads to reification ${ }^{4}$.

Debates on democracy as a concept (Collier et al. 2006) has not produced a consensus beyond the notion of "rule by the people". For the V-Dem approach, the solution is to conceptualize and measure several of the most accepted theories of democracy: electoral, liberal, egalitarian, participatory, and deliberative democracy (Coppedge et al. 2015a, Coppedge et al. n.d. 2016). Each of these varieties are conceptualized and measured as attributes of political systems (or "Country Units” in V-Dem jargon).

\section{Dichotomy or Degrees?}

Definitional discussions in comparative literature are frequently framed by the controversy between those who think democracy and non-democracy are best conceptualized as a dichotomy, or as two ends on a continuum (e.g. Collier and Adcock 1999). It should be recognized that this debate is a false one on one level. Any study has to make a distinction between phenomena that are objects of analysis and others that are not. Hence, the researcher always has to make a decision on differences in kind such as decide what is a regime that can potentially be a democracy, and what is not and therefore excluded from the analysis. Within that class of objects defined as units for analysis, however, further choices can be either of the kind-type or the degree variant. In the discussion of empirical democracy, scholars like Alvarez et al. (1996), Huntington (1991, 11-2), Geddes (1999), and Linz $(1975,184-5)$ rather vigorously argue in favor of a dichotomous approach. Speaking about democracy as a matter of degree is, in Sartori's words, a "stultifying" exercise in “degreeism" $(1987,184)$.

\footnotetext{
4 There are other dangers associated with this approach. One of them is the importance ascribed to the cut-off point. If the distribution of cases is U-shaped the share of classification error is reduced as most cases are distributed towards the ends of a thought continuum. The effect of a particular cut-off point of one particular rather than another are relatively small since there are few "grey-zone" cases. But with a distribution that is normal or even $\cap$ shaped, the selection of cut-off point naturally plays a greater role in producing the results. Even a small change in classificatory criteria will then result in a large number of cases being rearranged. Coppedge (1997) for example, have demonstrated that significantly different results emerge depending on which cut-off point is used to classify countries as either democracies or non-democracies.
} 
I share the position of Levitsky and Adcock (1999) calling for methodological - rather than philosophical - justifications. It is quite possible, and I would argue preferable, to work with a graded measure of democracy and use that graduation to establish and argue for a particular cut-off point between two or more regime types. When the distribution of cases along such a continuum is known, the sensitivity to errors by certain cut-off points can be assessed. If one starts out with only a dichotomy there is no way such a test can be performed and we will never know how great a role the classification criteria played in producing the results. In addition, scholars can certainly agree on basic defining characteristics of democracy, excluding purely authoritarian systems without necessarily agreeing on the theoretically or empirically valid cut-off points.

It seems that for example, Alvarez et al. (1996) fail to recognize that just because all regimes can be unambiguously classified as either democracy or non-democracy on basis of systematically generated empirical observations ${ }^{5}$, does not validate the theoretical argument for a binominal classification. The validity of the specification of a concept and its internal characteristics lies in its ability to address the research question. Thus, what is important is the ability of a dichotomous or a graded concept of democracy to engage in the kind of analysis the researcher sets.

Other scholars like Dahl in his formulation of polyarchy (1971, 2, 8; 1989, 316-7), and later Bollen and Jackman (1989, 612-8), Coppedge and Reinicke (1990), and Diamond (1996, 53), posit democracy is always a matter of degree with most countries along a continuum between full democracy and complete non-democracy. There are two main variants of this argument. The first ranks countries along an indexed continuum while the other situates them based on subordinate categories from partial to total democracies, referred to - sometimes - as "diminished subtypes". Diamond's (2002) typology ranging from closed authoritarian to full democracy with four intermediate categories, is frequently used, or adaptations of it, and it is an instance of this kind of degreeism that we associate with ordinal variables: we know that there is a difference between the categories and that there is a range from lowest/worst to most/best ${ }^{6}$. What we do not know is the exact distance between these categories. I have nothing against ordinal degrees-of-democracy approaches except that I think it is preferable if such emanates from a fully interval scale so - just

\footnotetext{
5 This reasoning partly avoids the more technical discussion of random and systematic errors. Alvarez et al. (1996) argue - correctly - that the bulk of errors resulting from classification of so-called borderline cases are systematic and their effect can therefore be measured and corrected for. They also argue that polychotomous scales generates smaller but more errors, while dichotomous scales generates larger but fewer of them. The latter, however, is dependent on the distribution of cases as discussed above which cannot be known unless a graded measure is used first.

${ }^{6}$ Whereas with nominal variables there is only a difference between categories with no ranking involved.
} 
like with dichotomies - the distances between categories and the usefulness of the cut-off points can be empirically assed.

Measures from Bollen (1979), Coppedge and Reinecke (1990), Marshall and Jaggers (2002), Polity IV, Bertelsman Transformation Index, the EIU's Democracy Index and so on, have at least the trappings of interval scales (although the strongly bimodal empirical distributions of for example Polity IV puts the scale into question). The degree approach tends to specify the range from zero to full without specifying a particular cut-off point ${ }^{7}$. Nevertheless, a cut-off point is always possible to identify and many do it even while keeping their graded measures (e.g. Coppedge and Reinecke 1990, Polity IV). I share the preference for a graded approach because it preserves information needed for research questions pertaining to democratization - which is a process whereby a political system becomes increasingly democratic ${ }^{8}$.

\section{What Democracy Is}

The most fundamental value modern democracy is arguably self-government. It seems to me that there is no substantial debate on this matter. But this is not to deny that there are other democratic values as well. The only point is to say that self-government as the freedom of individual citizens to rule over themselves through a concerted collective process, is logically the most fundamental of them all. In other words, the people should rule over itself, or, the people are sovereign. This sovereignty must be distributed equally since unequal distribution of sovereignty implies in fact that some segments of the people are not sovereign. This is what Locke referred to as all men are, or ought to, be considered equal as political beings ${ }^{9}$ (Locke 168990/1970, 322) and what Dahl calls the "idea of intrinsic equality" (1989, 85). In translating selfgovernment into reality, however, varying schools of thought have emphasized different sets of core values. The V-Dem approach defines five of the thus (and here I quote):

\footnotetext{
${ }^{7}$ Leaving aside here the difficult and unresolved issue of how to combine such measures into a single index of democracy. While Coppedge and Reinecke (1990) claim to have evidenced that democracy, understood as polyarchy, is uni-dimensional, Dahl himself (1971, 1989) and Bollen and Jackman (1989), Hadenius (1992), Vanhanen (1997) amongst others find democracy to consist of two or more dimensions. The methodological implications are many and complex. Most importantly, perhaps, is the fact that if democracy has two or more dimensions, the formula for combining these has to be established if indeed we search for a single scale. For example, do we use simple addition or multiplication of indicators? In metaphorical terms, are we measuring using meters or square meters; is democracy a long line or an area? If three or more dimensions are involved the possible geometric formulas increase to include a range of geometric figures. For excellent discussion of this and other intricate problems of measuring democracy, see Coppedge (2003), and Munck (2001a, 2001b).

${ }^{8}$ Needless to say, this is a conceptual point and should not be mistaken for a tautological empirical theory.

${ }^{9}$ At the time, of course, men meant just free men excluding the vast majority of the population. Without any intention of downplaying its significance, the difference is a matter of citizenship and not democratic principle, hence, is not central to the discussion here.
} 
"The electoral principle of democracy embodies the core value of making rulers responsive to citizens through periodic elections. In the V-Dem conceptual scheme, electoral democracy is captured by Robert Dahl's $(1971,1989)$ conceptualization of "polyarchy." It is the idea that democracy is achieved through competition among leadership groups, which vie for the electorate's approval during periodic elections before a broad electorate. Parties and elections are the critical instruments in this largely procedural account of the democratic process. Following Dahl, we also count the existence of freedom of association that goes beyond political parties, a free media and freedom of expression ensuring possibilities for enlightened understanding in selecting leaders, and alternative sources of information on the (in)actions of political elites. Although many additional factors might be regarded as important for ensuring and enhancing electoral contestation (e.g., additional civil liberties and an independent judiciary), these factors are often viewed as secondary to electoral institutions (Dahl 1956; Przeworski et al. 2000; Schumpeter 1950) and in the V-Dem scheme are classified as aspects of other principles of democracy.

In the V-Dem conceptual scheme, the electoral principle is important for all other conceptions of democracy. We also consider it fundamental: we would not want to call a regime without elections "democratic" in any sense. At the same time, countries can have "democratic qualities" without being complete polyarchies. We see it as a continuum.

We also recognize that the electoral principle in itself does not capture various understandings of democracy that emphasize non-electoral properties and that critique electoral democracy as being insufficient. These critiques have given rise to additional principles, each of which is designed to correct one or more limitations of electoral democracy.

- The liberal principle of democracy stresses the intrinsic value of protecting individual rights against potential "tyranny of the majority" and state repression. This is achieved through constitutionally protected civil liberties, strong rule of law, and effective checks and balances that limit the use of executive power. These are seen as defining features of the liberal aspect of democracy, not simply as aids to political competition. The liberal model takes a negative view of political power insofar as it judges the quality of democracy by the limits placed on government. ${ }^{10}$

- The majoritarian principle of democracy reflects the idea that the will of the majority should be sovereign. Accordingly, democracy is improved if it ensures that the many prevail over the few in terms of making decisions and act on policy issues thus boosting what is often referred to as governing capacity. This also reflects the ideal that one party should clearly be accountable to the electorate in order to make responsiveness possible. To facilitate this, political institutions should centralize and concentrate, rather than disperse, power (within the context of competitive elections). This may be facilitated by a unitary constitution,

\footnotetext{
${ }^{10}$ See Dahl (1956) on "Madisonian Democracy"; see also Gordon (1999), Hamilton, Madison \& Jay (1992), Hayek (1960), Held (2006, ch. 3), Hirst (1989), Mill (1958), Vile (1998).
} 
unicameralism, plurality electoral laws (or majoritarian two-round systems) leading to twoparty systems, governing party domination of legislative committees, no constitutional provisions for supermajorities, no or weak judicial review, and so forth—in other words, few veto players. ${ }^{11}$

- The consensual principle of democracy is in several ways the opposite to the majoritarian vision and emphasizes that the political institutions should encourage, in the extreme, mandate the inclusion of as many political perspectives as possible. Accordingly, democracy is improved in the consensual sense if it makes it easier for small groups to be represented in the political system and make their voices heard, and that require the national head of government to share power with other political actors and bodies. This also reflects the ideal that responsiveness is accomplished when each interest can have its own party represented. Consensual democracy therefore emphasizes proportional electoral laws making large party systems possible, having two (or more) legislative chambers, forming oversized multiparty cabinets, separating national and subnational political units (federalism), constitutional provisions of supermajorities, strong judicial review, among other attributes. $^{12}$

- The participatory principle of democracy embodies the values of direct rule and active participation by citizens in all political processes. It is usually viewed as a lineal descendant of the "direct" (i.e., non-representative) model of democracy. The motivation for participatory democracy is uneasiness about a bedrock practice of electoral democracy: delegating authority to representatives. Direct rule and involvement by citizens is preferred, wherever practicable. And within the context of representative government, the participatory element is regarded as the most democratic element of the polity. This model of democracy thus takes suffrage for granted, emphasizing turnout (actual voting) as well as non-electoral forms of participation such as citizen assemblies, party primaries, referenda, juries, social movements, public hearings, town hall meetings, and other forums of citizen engagement. ${ }^{13}$

- The deliberative principle of democracy enshrines the core value that political decisions in pursuit of the public good should be informed by respectful and reason-based dialogue at all levels rather than by emotional appeals, solidary attachments, parochial interests, or coercion. According to this principle, democracy requires more than an aggregation of existing preferences. It therefore focuses on the process by which decisions are reached in a polity. A deliberative process is one in which public reasoning focused on the common good motivates political decisions-as contrasted with emotional appeals, solidary attachments, parochial interests, or coercion. There should also be respectful dialogue at all levels-from preference formation to final decision-among informed and competent participants who are open to persuasion (Dryzek 2010: 1). "The key objective," writes David Held (2006: 237), "is the transformation of private preferences via a process of deliberation into positions that can withstand public scrutiny and test." Some political

\footnotetext{
${ }^{11}$ See American Political Science Association (1950), Bagehot (1963), Ford (1967), Goodnow (1900), Lijphart (1999), Lowell 1889), Ranney (1962), Schattschneider (1942), Wilson (1956).

12 Our definition of consensus democracy is almost identical to Lijphart's formal definition of consensus democracy (Lijphart 1999, 3-4). However, Lijphart's book, and his prior work on consociationalism, imply that his version of consensus democracy is designed to foster the inclusion of different religious, linguistic, or ethnic communities. We prefer to include these attributes in our egalitarian principle. See also Mansbridge (1983) and Powell (2000).

${ }^{13}$ See Barber (1988), Benelo \& Roussopoulos (1971), Dewey (1916), Fung \& Wright (2003), Macpherson (1977), Mansbridge (1983), Pateman (1976), Rousseau (1984), Young (2000).
} 
institutions serve a specifically deliberative function, such as consultative bodies (hearings, panels, assemblies, courts); polities with these sorts of institutions might be judged more deliberative than those without them. However, the more important issue is the degree of deliberativeness that can be discerned across all powerful institutions in a polity (not just those explicitly designed to serve a deliberative function) and among the citizenry. ${ }^{14}$

- The egalitarian principle of democracy holds that material and immaterial inequalities inhibit the actual use formal political (electoral) rights and liberties. It therefore addresses the goal of political equality across social groups - as defined by income, wealth, education, ethnicity, religion, caste, race, language, region, gender, sexual identity, or other ascriptive characteristics. Ideally, all groups should enjoy equal de jure and de facto capabilities to participate; to serve in positions of political power; to put issues on the agenda; and to influence policymaking. (This does not entail equality of power between leaders and citizens, as leaders in all polities are by definition more powerful.) Following the literature in this tradition, gross inequalities of health, education, or income are understood to inhibit the exercise of political power and the de facto enjoyment of political rights. Hence, a more equal distribution of these resources across social groups may be needed in order to achieve political equality. ${ }^{15}$,

(Quoted from: Coppedge et al. 2015a, p.20-23)

The principles behind, and V-Dem's methodology for constructing indices for these varieties of democracy is documented in Coppedge et al. 2015b, and in Skaaning et al. nd 2016. Each of these democracy-indices builds on combining several component, and often subcomponent, indices. For the construction of these component, and sub-component indices, see descriptions in the Codebook (Coppedge t al. 2015c) as well as several working papers on the polyarchy and the executive index (Teorell \& Lindberg 2015, nd 2016) on a long series of component and subcomponent indices (Teorell et al. nd 2016), on the party system institutionalization index (Hicken 2015), on the civil society core index (Bernard et al 2015), on the female empowerment index (Wang et al. 2015), and on the new egalitarian component index and its subcomponent indices (Sigman \& Lindberg 2015). ${ }^{16}$

All the V-Dem indices (regardless of level of aggregation) are normalized and scaled from 0 to 1 . This is fully in line with the conceptual argument above and useful for most sorts of linear regression techniques, including standard time-series, as well as cross sectional analyses.

\footnotetext{
${ }^{14}$ See Bohman (1998), Elster (1998), Fishkin (1991), Gutmann \& Thompson (1996), Habermas (1984, 1996), Held (2006, ch. 9), Offe (1997). A number of recent studies have attempted to grapple with this concept empirically; see Bächtiger (2005), Dryzek (2009), Mutz (2008), Ryfe (2005), Steiner et al. (2004), Thompson (2008).

${ }^{15}$ See Ake (1999), Berman (2006), Bernstein (1961, 1996), Dahl (1982, 1989), Dewey (1916, 1930), Dworkin (1987, 2000), Gould (1988), Lindblom (1977), Meyer (2007), Offe (1983), Sen (1999), Walzer \& Miller (1995). Many of the writings cited previously under participatory democracy might also be cited here. Taking a somewhat different stand on this issue, Beetham (1999) and Saward (1998: 94-101) do not request an equal distribution of resources. Rather, they consider access to basic necessities in the form of health care, education, and social security to be democratic rights as they make participation in the political process possible and meaningful.

${ }^{16}$ At the lowest level are the individual indicators drawn from the 400 or so V-Dem collects data on (for aggregation of coder-ratings to country-year indicators at the lowest level, see Pemstein et al. 2015).
} 
However, there are several other empirical strategies that are critical for important research questions in democratization (as well as for other substantial topics of course). Allow me just to mention a couple. One obvious need present in many cases is classification. Interval scales like VDem's indices ranging from 0 to 1 without any thresholds are necessarily unhelpful in this regard. While we learn a lot about smaller and bigger differences between countries in terms of degrees, we end up knowing nothing about which countries can be considered "democracies" in one understanding of the word or another, and which ones are not democracies. This is essential for survival analyses (e.g. seeking to answer the question “what makes democracy survive?”), but also for any analysis of democratization where that word is understood as "successful transition to democracy". Both these types of inquiries, requires imposing one or more thresholds if one starts with an interval scale. Or, if one desire a classification with higher degrees of fine tuning, we may want to analyze the differences between say minimally democratic countries and "fully" democratic ones, or to look at which types of autocratic regimes are more prone to becoming democracies such as closed autocracies and electoral authoritarian regimes. Again, an interval scale for all its beauty and advantages, does not help us address such topics.

Another substantially really important area of research, highly understudied until now, concerns sequences of democratization. There exist a number of approaches to identify sequences in time series data that are more or less inspired from evolutionary biology ${ }^{17}$ e.g. social sequence analyses that are inspired by DNA sequence analyses (e.g. Abbott 1995; Abbot \& Tsay 2000, Gauthier et al. 2010, Casper and Wilson 2015), qualitative comparative analysis (QCA) that are inspired by studies of evolutionary sequences (Ragin 1987; Rihoux \& Ragin 2009), and timeseries cross-section methods (Beck 2008). There also exists a more novel approach using Bayesian modelling to construe dynamic systems indicating flow of change (Ranganathan et al. 2014; Spaiser et al. 2014). In many ways, what the suggested analyses do is similar to what many readers will recognize as a Granger-test for time-series data, and some aspects probably remind readers of the standard technique of lagging variables in time-series, cross-sectional (TSCS) analyses.

There is one critical - and advantageous - difference between Granger-tests and the use of lags in TSCS and the combination of tools proposed here. The frequency and dependency analyses as well as the graphical approach presented below do not depend on specifying a specific time interval. We all know that the one or two, sometimes five, year intervals typically used are typically arbitrary and lack theoretical justifications. We do not know if, for example, improvements in civil liberties such as the freedom of discussion should be expected to be

\footnotetext{
17 The following paragraphs borrows from Lindenfors et al $n d 2015$.
} 
associated with improvements in say how clean elections are, one, five, ten or more years down the road. Furthermore, we have no theoretical reasons to (as standard techniques forces us to) assume that the time-lag between changes in $\mathrm{X}$ and changes in $\mathrm{Y}$ are expected to be constant across countries and over time. To the contrary, in some areas we have empirically based intuitions suggesting that we should expect time-variant time-lags.

The methods mentioned above (and adaptations for social science data structured like VDem data is discussed in detail in Lindenfors et al. nd 2015; for an application see Wang et al. 2015) does not require us to make any assumptions about either cross-section nor time-invariant distances in time between $\mathrm{X}$ and $\mathrm{Y}$. This is due to the reshaping of the observational data into "states" and changes between "states". A "state" simply means a fixed value ${ }_{\mathrm{i}}$ on variable $\mathrm{x}$ for a period of time ${ }_{\mathrm{t}}$. This structuring of the data then makes it possible to map and analyze identical sequences of change, even if the length of time that country A and country B are in various "states" vary across time and space.

Combining a series of such bivariate analyses (by essentially run all variables against all), one can establish long series of sequences involving hundreds of variables. The result is a detailed and empirically based "map" of which aspects of a phenomenon are more or less necessary conditions of other aspects. In other words, we are now capable of providing the first solution to presenting detailed sequences of democratization, and other similar phenomena. In order to generate readable results, this necessitates turning interval variables into identifiable ordinal variables. Hence, the V-Dem indices that are normalized on a scale from 0 to 1 are in need of a set of transformation rules to generate ordinal equivalents with three, four, and five states, or values.

First of all, since the V-Dem indices are scaled from 0 to 1, we can assume that as a general rule equidistant thresholds for a categorical version make sense. At the same time, for the roughest categorization with only three levels, we assume that the break point between being closer to the endpoint (.5) is critical for a distinction between country-years that are closer to the top/most democratic end of the scale, than to the most autocratic state. Thus for this categorization, we start with the .5 threshold and then further subdivide the lower category at .25 . Visual face validity checks comparing the results of such an approach with the original interval values have also corroborated our intuition (based on inspecting some 4,000 graphs). Thus for most indices, we have applied the following generic rule for the 3-level ordinal categorization, where $I$ denotes "index": 


\section{CATEGORIES}

$0.0:$ if $I>=0 \& I<=0.25$

$0.5:$ if $I>0.25 \& I<=0.5$

1.0: if $I>0.5 \& I<=1$

Correlations between the original interval indices and the ordinal versions with only three levels (as well as with one-year lagged versions of both) are surprisingly high across the over 20 indices, typically ranging from around .91 to .97. The main exception is the Direct Democracy Index (v2xdd_dd) were some correlations were at .77 to .80 . Hence, caution is advised if and when using the 3-level version of this index. All correlations reported here are found in the appendix to this paper.

Further analysis of the results from different options for the 4-level and 5-level ordinal versions, demonstrated that the assumption of equidistance matched the structure of the data very well, and produced high levels of face validity, as well as very strong correlations. Thus, for these versions, the following and most intuitive and mathematically "neutral" rules were applied:

$$
\begin{aligned}
& \text { 4 CATEGORIES } \\
& \text { 0.00: if } I>=0 \& I<=0.25 \\
& \text { 0.33: if } I>0.25 \& I<=0.5 \\
& \text { 0.67: if } I>0.5 \& I<=0.75 \\
& \text { 1.00: if } I>0.75 \& I<=1 \\
& \text { 5 CATEGORIES } \\
& \text { 0.00: if } I>=0 \& I<=0.2 \\
& \text { 0.25: if } I>0.2 \& I<=0.4 \\
& \text { 0.50: if } I>0.4 \& I<=0.6 \\
& \text { 0.75: if } I>0.6 \& I<=0.8 \\
& \text { 1.00: if } I>0.8 \& I<=1
\end{aligned}
$$

Again, correlations between these versions and the original indices, as well as with lagged versions of both, are very high typically around .96 to .98 . The Direct Democracy Index is again the main exception to this, with correlations at the .77 to .84 levels and caution is advised once more. Face validity is also high. Below are graphs for one country that has seen several drastic changes in regime status over the years, Ghana. In the first one, V-Dem's original, interval-scale index for Liberal Democracy is plotted against the ordinal versions that have three, four, and five categories respectively. 


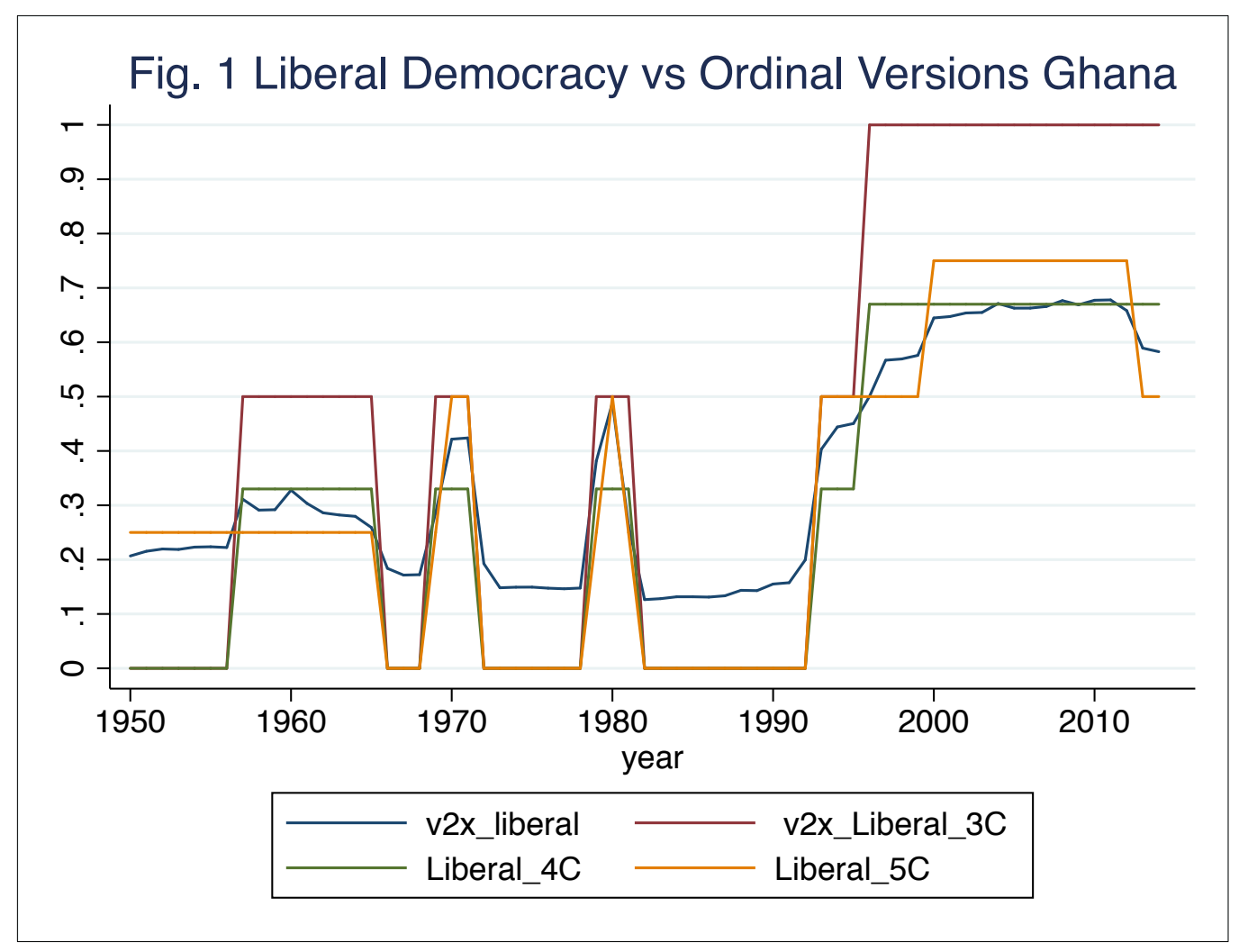

The blue line depicts the original Liberal Democracy index with a number of significant swings up and down over the over sixty years displayed here. Naturally, the ordinal versions of the index with the greater number of levels (4C and 5C) follow the trajectories of the original index more closely than the cruder three-level index. But as the reader can see, the overall developments are captured in very similar ways across the versions of the indices. Ghana's independence in 1957 , the coup unseating Kwame Nkrumah in 1966, the renewed elections in 1969, the return to military rule in 1972 when General Acheampong took power, the democratic interlude 1979-1981 followed by Jerry J. Rawlings autocratic rule until the opening in 1991 and elections in 1992. The Five-level ordinal version also picks up the first turnover to the NPPgovernment in the elections in 2000. The authors has produced many thousands of such graphs across all indices produced by V-Dem, and inspected them for face validity. Generally, the example above from Ghana is pretty representative. Most cases look like this. Hence, when one have the need for an ordinal version of one of the indices for sequence analysis or maximumlikelihood estimations, the indices produced here (and found in Section B of the V-Dem Codebook), are good alternatives.

For the V-Dem index for electoral democracy (v2x_polyarchy) and the related but more narrowly defined index for elections (v2x_EDcomp_thick), analysis provide strong evidence that a categorization with high face validity and high correlations is dependent on capturing a conditional relationship to two critical variables when it comes to the 3- and 4-level 
categorizations. The two key variables measure to what extent elections are multiparty (v2elmulpar) and to what extent the elections were overall free and fair (v2elfrfair).

Generally, it was face validity analyses that provided the strongest empirical basis for this conclusion. With the "cruder" categorizations of only three or four levels using only the unconditional distance rules for thresholds as for most other indices, it was clear that countries just slightly above a threshold could be of very varying democratic quality. This is the result of the aggregation rule for the original interval V-Dem index for electoral democracy, which is in part multiplicative and in part additive:

$$
\begin{aligned}
& \text { v2x_polyarchy= } \\
& .1 *_{\mathrm{v}} 2 \mathrm{x} \_ \text {suffr }+.1 *_{\mathrm{v}} 2 \mathrm{xel} \_ \text {frefair }+.1 *_{\mathrm{v}} 2 \mathrm{x} \_ \text {accex }+.1 *_{\mathrm{v}} 2 \mathrm{x} \_ \text {frassoc_thick } \\
& +.1 * \mathrm{v} 2 \mathrm{x} \_ \text {freexp_thick } \\
& +.5 * \mathrm{v} 2 \mathrm{x} \_ \text {suffr } * \mathrm{v} 2 \mathrm{xel} \_ \text {frefair } * \mathrm{v} 2 \mathrm{x} \_ \text {accex } * \mathrm{v} 2 \mathrm{x} \_ \text {frassoc_thick } * \mathrm{v} 2 \mathrm{x} \_ \text {freexp_thick }
\end{aligned}
$$

Thus for example, countries with full suffrage, substantial freedom of expression and some level of freedom of association but completely fraudulent elections can by the additive term reach a similar level to a country with decent elections but more of issues with for example freedom of expression. In the end, the following "ordinalization rules" provide high correspondence between the original values of the indices, and highest face validity (again based on inspection of thousands of graphs, each covering some 100 years of political history for a particular country):

\section{CATEGORIES}

0.0 : if v2x_polyarchy $>=0 \& \mathrm{v} 2 \mathrm{x} \_$polyarchy $<=0.25$

0.0 : if $v 2 x \_$polyarchy $>0.25 \& \mathrm{v} 2 \mathrm{x} \_$polyarchy $<=0.5$

\& v2elmulpar_osp $>=0$ \& v2elmulpar_osp $<=2.5$

0.0 : if v2x_polyarchy $>0.25 \& \mathrm{v} 2 \mathrm{x} \_$polyarchy $<=0.5$

\& v2elfrfair_osp $>=0 \&$ v2elfrfair_osp $<=2$

$0.5:$ if v2x_polyarchy $>0.25 \& \mathrm{v} 2 \mathrm{x} \_$polyarchy $<=0.5$

$\&$ v2elmulpar_osp $>2.5 \&$ v2elmulpar_osp $<=4$

0.5 : if v2x_polyarchy $>0.25 \& \mathrm{v} 2 \mathrm{x} \_$polyarchy $<=0.5$

$\&$ v2elfrfair_osp $>2 \&$ v2elfrfair_osp $<=4$

0.5 : if v2x_polyarchy $>0.5 \& \mathrm{v} 2 \mathrm{x} \_$polyarchy $<=1$

$\&$ v2elfrfair_osp $>=0 \&$ v2elfrfair_osp $<3$

1.0: if v2x_polyarchy $>0.5 \& \mathrm{v} 2 \mathrm{x} \_$polyarchy $<=1$

$\&$ v2elfrfair_osp $>=3 \&$ v2elfrfair_osp $<=4$

\section{CATEGORIES}

0.00 : if v2x_polyarchy $>=0 \&$ v2x_polyarchy $<=0.25$

0.00 : if v2x_polyarchy $>0.25 \& \mathrm{v} 2 \mathrm{x} \_$polyarchy $<=0.5$

\& v2elmulpar_osp $>=0$ \& v2elmulpar_osp $<=2$

0.00 : if $\mathrm{v} 2 \mathrm{x} \_$polyarchy $>0.25 \& \mathrm{v} 2 \mathrm{x} \_$polyarchy $<=0.5$

\& v2elfrfair_osp $>=0$ \& v2elfrfair_osp $<=2$

0.33: if v2x_polyarchy $>=0.250001 \& \mathrm{v} 2 \mathrm{x} \_$polyarchy $<=0.5$

$\&$ v2elmulpar_osp $>2 \&$ v2elmulpar_osp $<=4$ 
0.33: if $\mathrm{v} 2 \mathrm{x} \_$polyarchy $>0.25 \& \mathrm{v} 2 \mathrm{x} \_$polyarchy $<=0.5$

\& v2elfrfair_osp $>2$ \& v2elfrfair_osp $<=4$

0.67: if v2x_polyarchy $>0.5$ \& v2x_polyarchy $<=1$

\& v2elfrfair_osp $>2 \&$ v2elfrfair_osp $<3 \&$ v2elmulpar_osp $>2$

1.00: if v2x_polyarchy $>0.5 \quad \&$ v2x_polyarchy $<=1$

\& v2elfrfair_osp $>3 \&$ v2elmulpar_osp $>3$

The same logic and conditions then applies to transformation to ordinal versions of the electoral component index (v2x_EDcomp_thick) and the clean elections index (v2x_el_frefair). The correlations are again very high with the expected pattern of higher correlations the greater number of levels in the categorical versions of the indices, but all typically above 96 .

But even more importantly (one can argue), the tracking of the ordinal versions of the indices with the original interval scale over time for the 173 countries in the V-Dem dataset, display a very high level of face validity. In the process of testing many alternative thresholds and inspecting almost 10,000 country graphs, these thresholds and conditions seem to make a lot of sense. Below, I have inserted the graphs for the Electoral Demcoracy Index. We stay with the Ghanaian example.

Fig. 1 Electoral Democracy vs Ordinal Versions Ghana

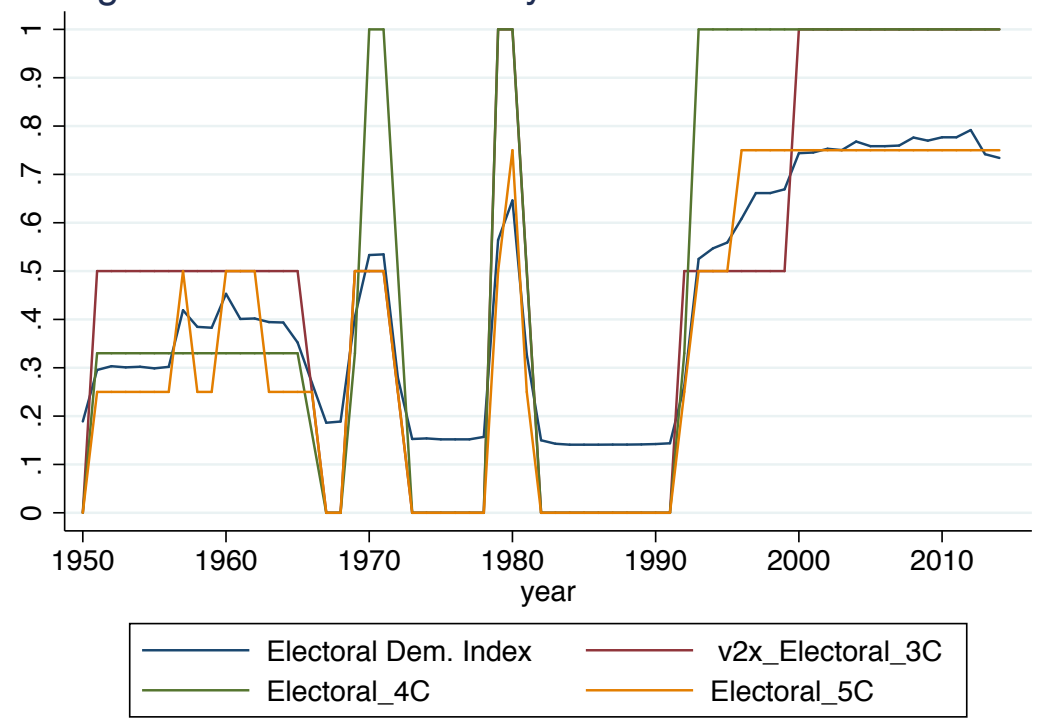

Again, the "crude" ordinal versions track almost surprisingly well on the Electoral Democracy index. There are occasional "wide swings" up and down when a country oscillates around one of the thresholds, but there are surprisingly few of those. And it is an unavoidable effect of categorizing unless you implement some smoothing function/time rule to essentially ignore those swings in the original indices. The country graphs for all indices and countryes are available for inspection on request to the author, as so is the complete STATA do-file for generating indices. Appendix B reports on all correlations. 


\section{Conclusion}

This paper makes the argument that for many descriptive purposes, as well as a series of important analytical endeavors, interval indices are not particularly useful (despite their many important advantages). Indices like all the ones V-Dem produces are thus in need of ordinal versions allowing for survival analyses, classification of regime categories, understanding and explaining successful transitions to democracy, breakdown of democratic regimes, as well as for the emerging area of sequence analysis.

Second, this paper advances a set of coding rules that transforms the existing, original VDem indices to ordinal indices with three, four and five levels respectively. Users can determine which level of distinction is most useful for the research project, or the task of descriptive representation at hand. For the democracy indices that V-Dem supplies at the highest level of aggregation, the paper also suggests a classification of the levels into varying regime types.

The resulting three ordinal versions of all of the $35 \mathrm{~V}$-Dem indices are validated both by high correlations with the original indices, as well as by inspection of face validity over some over 10,000 graphs, each one comparing one of the three ordinal versions with the original index from 1900 to 2012 for a particular country. 


\section{References}

Abbott, Andrew, Tsay Angela. 2000. "Sequence Analysis and Optimal Matching Methods in Sociology". Sociological Methods and Research 29: 3-33.

Abbott, Andrew. 1995. “Sequence Analysis: New Methods for Old Ideas”. Annual Review of Sociology 21: 93-113.

Ake, Claude. 1999. The Feasibility of Democracy in Africa. Dakar: CODRESIA.

Alvarez Michael, Cheibub Jose A., Limongi Fernando, Przeworski Adam. 1996. "Classifying Political Regimes". Studies in Comparative International Development 31(2): 3-36.

American Political Science Association. 1950. Toward a More Responsible Two-Party System. New York: Holt, Rinehart.

Bächtiger, André. ed. 2005. "Empirical Approaches to Deliberative Democracy." Special issue Acta Politica 40(1-2).

Bagehot, Walter. 1963 [1867]. The English Constitution. Ithaca: Cornell University Press.

Barber, Benjamin. 1988. The Conquest of Politics: Liberal Philosophy in Democratic Times. Princeton: Princeton University Press.

Beck, N. 2008. "Time-series-cross-section methods". Oxford Handbook of Political Methodology. 47593.

Beetham, David. 1999. Democracy and Human Rights. Cambridge: Polity.

Benelo, George C. and Dimitrios Roussopoulos. 1971. The Case for Participatory Democracy: Some Prospects for a Radical Society. New York: Viking Press.

Berman, Sheri. 2006. Social Democracy and the Making of Europe's Twentieth Century. Cambridge University Press.

Berman, Sheri. 2006. Social Democracy and the Making of Europe's Twentieth Century. Cambridge University Press.

Bernhard Michael, Hicken Allen, Reenock Christopher, Lindberg Staffan I. 2015. Institutional Subsystems and the Survival of Democracy: Do Political and Civil Society Matter?. The Varieties of Democracy Institute. University of Gothenburg, Department of Political Science. Working Paper series 2015:4

Bernstein, Eduard. 1961. Evolutionary Socialism: A Criticism and Affirmation, Random House.

Bernstein, Eduard. 1996. Selected Writings of Eduard Bernstein, 1900-1921. Prometheus Books.

Bohman, James. 1998. "Survey Article: The Coming of Age of Deliberative Democracy." Journal of Political Philosophy 6(4): 400-425.

Bollen Kenneth A., Robert W. Jackman. 1989. "Democracy, Stability, and Dichotomies". American Sociological Review 54(4): 612-621 
Bollen, Kenneth. 1979. "Political Democracy and the Timing of Development". American Sociological Review 44(4): 527-587.

Collier David, Mahon James. 1993. “Conceptual 'Stretching' Revisited: Adapting Categories in Comparative Analysis". American Political Science Review 87: 845-55.

Collier David, Robert Adcock. 1999. "Democracy and Dichotomies: A Pragmatic Approach to Choices about Concept". Annual Review of Political Science 2: 537-65.

Collier Paul, Anke Hoeffler and Måns Söderbom. 2006. Post-Conflict Risks. Centre for the Study of African Economies.

Coppedge Michael, Gerring John, Lindberg Staffan I., Skaaning Svend-Erik, and Teorell Jan. 2015a. "Varieties of Democracy: Comparisons and Contrasts". Varieties of Democracy (VDem) Project.

Coppedge Michael, Gerring John, Lindberg Staffan I., Skaaning Svend-Erik, Teorell Jan, Altman

David, Andersson Frida, Bernhard Michael, Fish M. Steven, Glynn Adam, Hicken Allen, Knutsen Carl Henrik, Marquardt Kyle, McMann Kelly, Mechkova Valeriya, Pemstein Daniel, Pernes Josefine, Skaaning Svend-Erik, Staton Jeffrey, Stepanova Natalia, Tzelgov Eitan, Wang Yi-ting, and Zimmerman Brigitte. 2015b. "Varieties of Democracy: Methodology" v4. Varieties of Democracy (V-Dem) Project.

Coppedge Michael, Reinicke Wolfgang H.. 1990. "Measuring Polyarchy." Studies in Comparative International Development 25(1): 51-72.

Coppedge, Michael Staffan I. Lindberg, Svend-Erik Skaaning, and Jan Teorell. n.d. 2016. "Measuring High Level Democratic Principles Using the V-Dem Data". International Political Science Review 36

Coppedge, Michael. 1997. "Modernization and thresholds of democracy: evidence for a common path and process". In Inequality, Democracy, and Economic Development, ed. Manus Midlarsky. New York: Cambridge University Press.

Coppedge, Michael. 2005. "Thickening Thin Concepts: Issues in Large-N Data Generation”. In

Munck, Gerardo ed., Regimes and Democracy in Latin America, Vol. II: Methods and Data Oxford: Oxford University Press.

Dahl, Robert A. 1989. Democracy and its Critics. New Haven: Yale University Press.

Dahl, Robert A. 1956. A Preface to Democratic Theory. Chicago: University of Chicago Press.

Dahl, Robert A. 1971. Polyarchy: Participation and Opposition. Yale University Press.

Dahl, Robert A. 1982. Dilemmas of Pluralist Democracy. New Haven: Yale University Press.

Dewey, John. 1916. Democracy and Education. New York: The Free Press.

Dewey, John. 1930. Individualism. Minton, Balch \& Company. 
Diamond Larry, Marc F. Plattner. 2006. Electoral Systems and Democracy. Baltimore: Johns Hopkins University Press.

Diamond, Larry. 1996. Democracy in Latin America: Degrees, Illusions, and Directions for Consolidation. In Farer, Tom J. ed. Beyond sovereignty: Collectively Defending Democracy in the Americas. Baltimore: John Hopkins University Press.

Diamond, Larry. 2002. "Elections Without Democracy: Thinking about Hybrid Regimes". Journal of Democracy 13(2): 21-35.

Dryzek, John S. 2009. "Democratization as Deliberative Capacity Building." Comparative Political Studies 42(11): 1379-1402.

Dryzek, John S. 2010. Foundations and Frontiers of Deliberative Governance. Oxford: Oxford University Press.

Dworkin, Ronald. 1987. Law's Empire. Cambridge: Harvard University Press.

Dworkin, Ronald. 2000. Sovereign Virtue: The Theory and Practice of Equality, Cambridge, MA: Harvard University Press.

Elster, Jon. 1998. Deliberative Democracy. Cambridge: Cambridge University Press.

Fishkin, James S. 1991. Democracy and Deliberation: New Directions for Democratic Reform. New Haven: Yale University Press.

Ford, Henry Jones. 1898/1967. The Rise and Growth of American Politics. New York: Da Capo.

Fung, Archon, Erik Olin Wright. 2003. Deepening Democracy: Institutional Innovations in Empowered Participatory Governance. London: Verso.

Gauthier, Jacques-Antoine, Eric D. Widmer, Philip Bucher, Cédric Notredame. 2010. "Multichannel sequence analysis applied to social science data." Sociological Methodology 40(1): 138.

Geddes, Barbara. 1999. "What do We Know about Democratization after Twenty Years?". Annual Review of Political Science 2: 115-144.

Goodnow, Frank J. 1900. Politics and Administration. New York: Macmillan.

Gordon, Scott. 1999. Controlling the State: Constitutionalism from Ancient Athens to Today. Cambridge: Harvard University Press.

Gould, Carol C. 1988. Rethinking Democracy: Freedom and Social Cooperation in Politics, Economy, and Society. Cambridge, U.K.: Cambridge University Press.

Gutmann, Amy, and Dennis Thompson. 1996. Democracy and Disagreement. Cambridge: Harvard University Press.

Habermas, Jurgen. 1984. The Theory of Communicative Action. Volume One: Reason and the Rationalization of Society. Boston: Beacon Press. 
Habermas, Jurgen. 1996. Between Facts and Norms: Contributions to a Discourse Theory of Law and Democracy. Cambridge: MIT Press.

Hadenius, Axel. 1992. Democracy and Development. Cambridge: Cambridge University Press.

Hamilton, Alexander, James Madison, and John Jay. 1992 [1787-88]. The Federalist. Ed. William R. Brock. London: Everyman/J.M. Dent.

Hayek, Friedrich A. 1960. The Constitution of Liberty. London: Routledge \& Kegan Paul.

Held, David. 2006. Models of Democracy, 3d ed. Cambridge: Polity Press.

Hirst, Paul Q. 1989. The Pluralist Theory of the State: Selected Writings of G.D.H. Cole, J.N. Figgis, and H.J. Laski. New York: Routledge.

Huntington, Samuel P. 1991. The Third Wave: Democratization in the Late Twentieth Century. Norman, OK: University of Oklahoma Press.

Levitsky Steven, Robert Adcock. 1999. 'Democracy and Dichotomies: A Pragmatic Approach to Choices about Concepts". Annual Review of Political Science 2: 537-565.

Lijphart, Arend. 1999. Patterns of Democracy. New Haven: Yale University Press.

Lindberg, Staffan I. 2006. Democracy and Elections in Africa. Baltimore: Johns Hopkins University Press. Translated and reprinted in Chinese by Yilin Press (forthcoming 2016)

Lindberg, Staffan I. 2009. Democratization by Elections: A New Mode of Transition?. Baltimore: Johns Hopkins University Press

Lindberg, Staffan I. 2013. "Mapping Accountability: Core Concept and Subtypes". International Review of Administrative Sciences. 79(2): 202 - 226.

Lindberg, Staffan I., Michael Coppedge, John Gerring, and Jan Teorell. 2014. “A New Way to Measuring Democracy”. Journal of Democracy 25(3): 159-169.

Lindblom, Charles E. 1977. Politics and Markets: The World's Political-Economic Systems. New York: Basic Books. Lively, Jack. 1975. Democracy. Oxford: Basil Blackwell.

Lindenfors, Patrik, Fredrik Jansson, Yi-ting Wang and Staffan I. Lindberg. 2016.

Linz, Juan J. 1975. Totalitarian and Authoritarian Regimes. In Greenstein, F. I. and N.W. Polsby. eds. Handbook of Political Science 3. Reading: Addison-Wesley.

Locke, John. 2001b. “The Regime Question: Theory Building in Democracy Studies”. World Politics 54: 119-144.

Locke, John. 1689-90/1970. Two Treaties of Government. $2^{\text {nd }}$ ed. Cambridge: Cambridge University Press.

Lowell, A. Lawrence. 1889. Essays on Government. Boston: Houghton Mifflin.

Macpherson, C.B. 1977. The Life and Times of Liberal Democracy. Oxford: Oxford University

Mansbridge, Jane. 1983. Beyond Adversarial Democracy. Chicago: University of Chicago Press. 
Marshall Monty G., Jaggers Keith. 2002. Polity IV project: Political regime characteristics and transitions, 1800-2002. Center for International Development and Conflict Management. College Park: University of Maryland.

Meyer, Thomas. 2007. The Theory of Social Democracy. Cambridge: Polity Press

Mill, John Stuart. 1958 [1865]. Considerations on Representative Government, 3d ed., ed. Curren V. Shields. Indianapolis: Bobbs-Merrill.

Munck, Gerardo L. 1994. "Democratic Transitions in Comparative Perspective". Comparative Politics 26: 355-375.

Munck, Gerardo L. 2001b. “The Regime Question: Theory Building in Democracy Studies”. World Politics 54: 119-144.

Mutz, Diana C. 2008. “Is Deliberative Democracy a Falsifiable Theory?” Annual Review of Political Science 11: 521-538.

Offe, Claus. 1983. "Political Legitimation through Majority Rule?", Social Research 50 (4): 709756.

Offe, Claus. 1997. "Micro-aspects of Democratic Theory: what makes for the deliberative competence of citizens?" in: Hadenius, Axel (ed.), Democracy's Victory and Crisis (Cambridge: Cambridge UP) 81-104.

Pateman, Carole. 1976. Participation and Democratic Theory. Cambridge: Cambridge University Press.

Pemstein, Daniel, Eitan Tzelgov and Yi-ting Wang. 2015. "Evaluating and Improving Item Response Theory Models for Cross-National Expert Surveys". University of Gothenburg, Varieties of Democracy Institute: V-Dem Working Paper No. 1.

Pemstein, Daniel, Kyle Marquardt, Eitan Tzelgov, Yi-ting Wang and Farhad Miri. 2015. “The VDem Measurement Model: Latent Variable Analysis for Cross-National and Cross-Temporal Expert-Coded Data”. University of Gothenburg, Varieties of Democracy Institute: V-Dem Working Papers Series No. 21

Powell, G. Bingham. 2000. Elections as Instruments of Democracy: Majoritarian and Proportional Visions. New Haven: Yale University Press.

Przeworski Adam, Michael E. Alvarez, José A. Cheibub, and Fernando Limongi. 2000. Democracy and Development: Political Institutions and Well-Being in the World, 1950-1990. Cambridge: Cambridge University Press.

Ragin, C. C. 1987. The comparative method: Moving beyond qualitative and quantitative strategies. University of California Press.

Ranganathan S., V. Spaiser, R. P Mann., and D. J Sumpter. 2014. "Bayesian dynamical systems modelling in the social sciences". PloS one, 9(1), e86468. 
Ranney, Austin. 1962. The Doctrine of Responsible Party Government: Its Origins and Present State. Urbana: University of Illinois.

Rihoux, B., C. C Ragin. 2009. Configurational comparative methods: Qualitative comparative analysis (QCA) and related techniques. Sage.

Rousseau, Jean-Jacques. 1984. A Discourse On Inequality. Trans. by Maurice Cranston. Middlesex, England: Penguin.

Ryfe, David M. 2005. "Does Deliberative Democracy Work?”' Annual Review of Political Science 8: 49-71.

Sartori, Giovanni. 1984. Guidelines for Conceptual Analysis. In Sartori, Giovanni. ed. Social Science Concepts: A Systematic Analysis. Beverly Hills: Sage Publication.

Sartori, Giovanni. 1987. The Theory of Democracy Revisited Chatham. N.J.: Chatham House Publishers.

Saward, Michael. 1998. The Terms of Democracy. Oxford: Polity.

Schattschneider, E.E. 1942. Party Government. New York: Rinehart.

Schedler, Andreas. 2001a. "Measuring Democratic Consolidation". Studies in Comparative International Development 36(1): 66-92.

Schumpeter, Joseph A. 1950 [1942]. Capitalism, Socialismand Democracy. New York: Harper \& Bros.

Sen, Amartya. 1999. "Democracy as a Universal Value.” Journal of Democracy 10 (July) 3-17.

Sigman Rachel, Staffan I. Lindberg. 2015. "The Principle of Egalitarian Democracy: V-Dem's Conceptualization and Measurement". Varieties of Democracy Institute: Working Papers Series No. 21

Sigman Rachel, Staffan I. Lindberg. 2015. "The Principle of Egalitarian Democracy: V-Dem's Conceptualization and Measurement." Varieties of Democracy Institute: Working Papers Series No. 21

Spaiser V., Ranganathan S., Mann, R. P., Sumpter, D. J. (2014). "The dynamics of democracy, development and cultural values". PloS on 9(6), e97856.

Steiner, Jurg, Andre Bachtiger, Markus Sporndli, and Marco R. Steenbergen. 2004. Deliberative Politics in Action: Analysing Parliamentary Discourse. Cambridge: Cambridge University Press.

Teorell Jan and Staffan I. Lindberg n.d. 2016. "Measuring Electoral Democracy with V-Dem Data: Introducing a New Polyarchy Index". University of Gothenburg, Varieties of Democracy Institute: Working Papers Series No. 23

Teorell Jan, Lindberg Staffan I. 2015a. "The Structure of the Executive in Authoritarian and Democratic Regimes: Regime Dimensions across the Globe, 1900-2014”. The Varieties of Democracy Institute. University of Gothenburg, Department of Political Science. Working 
Paper series 2015:5

Teorell Jan, Rachel Sigman, and Staffan I. Lindberg. n.d. 2016. "V-Dem Indices: Rationale and Aggregations". University of Gothenburg, Varieties of Democracy Institute: Working Papers Series No. 22

Teorell, Jan and Staffan I. Lindberg. 2015. "The Structure of the Executive in Authoritarian and

Democratic Regimes: Regime Dimensions across the Globe, 1900-2014". University of Gothenburg, Varieties of Democracy Institute: Working Papers Series No.5

Teorell, Jan. 2011. "Over Time, Across Space: Reflections on the Production and Usage of Democracy and Governance Data." Comparative Democratization 9:1 (February) 1, 7.

Thompson, Dennis F. 2008. "Deliberative Democratic Theory and Empirical Political Science." Annual Review of Political Science 11: 497-520.

Vanhanen, Tatu. 1997. Prospects of Democracy. Psychology Press.

Vile, M.J.C. 1967/1998. Constitutionalism and the Separation of Powers. Liberty Fund.

Walzer Michael, David Miller. 1995. Pluralism, Justice, and Equality. Oxford: Oxford University Press.

Wang Yi-ting, Patrik Lindenfors, Aksel Sundström, Fredrik Jansson, Staffan I. Lindberg 2015.

“No Democratic Transition Without Women's Rights: A Global Sequence Analysis 1900-

2012". The Varieties of Democracy Institute. University of Gothenburg, Department of Political Science. Working Paper series 2015:12

Wang, Yi-ting, Aksel Sundström, Pamela Paxton, and and Staffan I. Lindberg. 2015. "Women's

Political Empowerment Index: A New Measure". University of Gothenburg, Varieties of Democracy Institute: Working Papers Series No. 18.

Wilson, Woodrow. 1956 [1885]. Congressional Government. Baltimore: Johns Hopkins University Press.

Young, Iris M. 2000. Inclusion and Democracy. Oxford University Press. 


\section{Appendix A: Correlations}

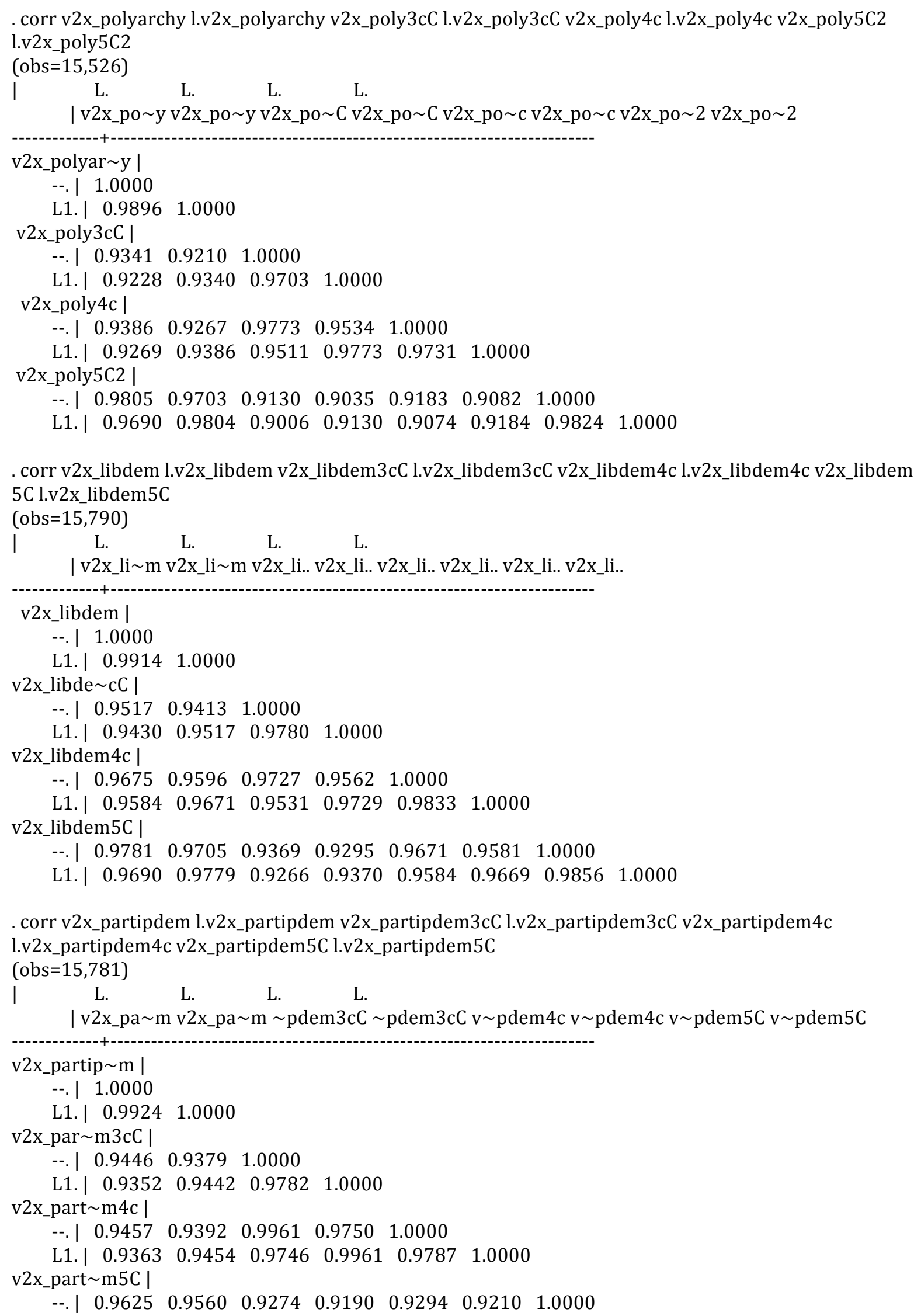




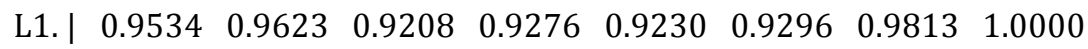

. corr v2x_egaldem3cC v2x_egaldem3cC v2x_egaldem4c

(obs $=14,449$ )

| v2x_e $\sim \mathrm{cC}$ v2x_e $\sim \mathrm{cC}$ v ldem $4 \mathrm{c}$

v2x_egald $\sim \mathrm{CC} \mid 1.0000$

v2x_egald cC | 1.00001 .0000

v2x_egald 4c| 0.97120 .97121 .0000

. corr v2x_egaldem l.v2x_egaldem v2x_egaldem 3cC l.v2x_egaldem3cC v2x_egaldem4c l.v2x_egaldem4c v2x_egaldem5C l.v2x_egaldem5C

(obs=14,246)

I L. L. L. L.

| v2x_eg m v2x_eg m v2x_e $\sim$ cC v2x_e $\sim \mathrm{cC}$ v $\sim \operatorname{ldem} 4 \mathrm{c}$ v $\sim \operatorname{ldem} 4 \mathrm{c}$ v $\sim \operatorname{ldem} 5 \mathrm{C}$ v $\sim \operatorname{ldem} 5 \mathrm{C}$

v2x_egaldem |

-- . 1.0000

L1. | 0.99351 .0000

v2x_egald $\sim \mathrm{cC} \mid$

\begin{tabular}{l|lll}
.-- & 0.9401 & 0.9325 & 1.0000
\end{tabular}

L1. | $0.9335 \quad 0.9402 \quad 0.9786 \quad 1.0000$

v2x_egald $\sim 4 \mathrm{c}$

--. | $0.9620 \quad 0.9566 \quad 0.9712 \quad 0.9554 \quad 1.0000$

L1. | $0.9546 \quad 0.9618 \quad 0.9523 \quad 0.9714 \quad 0.9838 \quad 1.0000$

v2x_egald $\sim 5 \mathrm{C}$ |

$\begin{array}{llllllll}--. & 0.9753 & 0.9691 & 0.9245 & 0.9190 & 0.9496 & 0.9435 & 1.0000\end{array}$

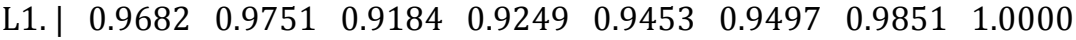

. corr v2x_delibdem l.v2x_delibdem v2x_delibdem 3cC l.v2x_delibdem3cC v2 $x_{-}$delibdem4c l.v2x_delibdem4c v2x_delibdem5C l.v2x_delibdem5C

(obs $=15,604$ )

L. L. L. L. L.

| v2 $x_{-}$de $\sim \mathrm{m}$ v $2 \mathrm{x}_{-} \mathrm{de} \sim \mathrm{m}$ v $2 \mathrm{x}_{-} \mathrm{d} \sim \mathrm{cC}$ v2 $\mathrm{x}_{-} \mathrm{d} \sim \mathrm{cC}$ v $2 \mathrm{x}_{-} \mathrm{d} \sim 4 \mathrm{c}$ v $2 \mathrm{x}_{-} \mathrm{d} \sim 4 \mathrm{c}$ v2 $\mathrm{x}_{-} \mathrm{d} \sim 5 \mathrm{C}$ v $2 \mathrm{x} \_\mathrm{d} \sim 5 \mathrm{C}$

v2x_delibdem |

-- | 1.0000

L1. | 0.98931 .0000

v2x_delib $\sim$ cC |

--. $0.95590 .9438 \quad 1.0000$

L1. | $0.9437 \quad 0.95590 .9731 \quad 1.0000$

v2x_delib 4c|

$\begin{array}{llllll}-- \text {. } & 0.9678 & 0.9585 & 0.9724 & 0.9518 & 1.0000\end{array}$

L1. | $0.9556 \quad 0.9676 \quad 0.9485 \quad 0.9726 \quad 0.9788 \quad 1.0000$

v2x_delib 5C |

\begin{tabular}{l|lllllll}
.-- & 0.9781 & 0.9684 & 0.9455 & 0.9344 & 0.9635 & 0.9526 & 1.0000
\end{tabular}

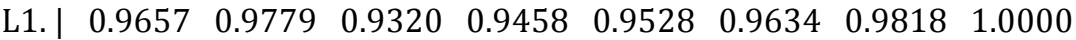

.corr v2x_freexp l.v2x_freexp v2x_freexp3cC l.v2x_freexp3cC v2x_freexp4c l.v2x_freexp4c v2x_freexp5C l.v2x_freexp5C

(obs $=15,779$ )

L. $\quad$ L. $\quad$ L. $\quad$ L.

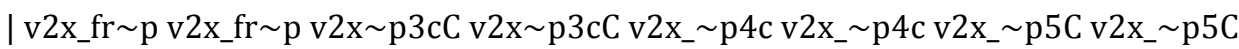

v2x_freexp |

$--. \mid 1.0000$

L1. | 0.98641 .0000

v2x_freex cC | 
$--. \mid 0.9138 \quad 0.8989 \quad 1.0000$

L1. | $0.9006 \quad 0.91390 .96891 .0000$

v2x_freexp4c|

$\begin{array}{llllll}-- & 0.9715 & 0.9576 & 0.9505 & 0.9271 & 1.0000\end{array}$

L1.| $0.9578 \quad 0.9715 \quad 0.9256 \quad 0.9507 \quad 0.9762 \quad 1.0000$

v2x_freexp5C |

\begin{tabular}{l|lllllll}
-- & 0.9825 & 0.9686 & 0.8975 & 0.8854 & 0.9534 & 0.9407 & 1.0000
\end{tabular}

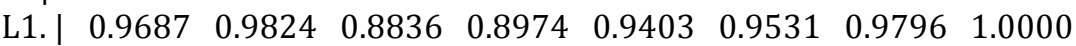

.corr v2xme_altinf l.v2xme_altinf v2xme_altinf3cC l.v2xme_altinf3cC v2xme_altinf4c l.v2xme_altinf4c v2xme_altinf5C l.v2xme_altinf5C

(obs=15,797)

I L. L. L. L.

| v2xme_ $\sim \mathrm{f}$ v2xme_ f v2xme $\sim \mathrm{cC}$ v2xme $\sim \mathrm{cC}$ v2xme $4 \mathrm{c}$ v2xme $4 \mathrm{c}$ v2 $2 \mathrm{xme} \sim 5 \mathrm{C}$ v2xme $5 \mathrm{C}$

v2xme_altinf |

$--\mid 1.0000$

L1. | 0.98731 .0000

v2xme_alt $\sim \mathrm{cC}$ |

$\begin{array}{llll}-- & 0.9244 & 0.9103 & 1.0000\end{array}$

L1.| $0.91260 .9243 \quad 0.9751 \quad 1.0000$

v2xme_alt $4 \mathrm{c}$ |

\begin{tabular}{l|lllll}
-- & 0.9763 & 0.9633 & 0.9549 & 0.9364 & 1.0000
\end{tabular}

L1.| $0.9633 \quad 0.9762 \quad 0.9340 \quad 0.9550 \quad 0.9801 \quad 1.0000$

v2xme_alt $5 \mathrm{C}$ |

$\begin{array}{llllllll}--. & 0.9841 & 0.9714 & 0.9096 & 0.8990 & 0.9596 & 0.9477 & 1.0000\end{array}$

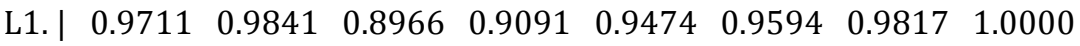

. corr v2x_EDcomp_thick l.v2x_EDcomp_thick v2x_EDcomp_thick3cC l.v2x_EDcomp_thick3cC v2x_EDcomp_thick4c l.v2x_EDcomp_thick4c v2x_EDcomp_thick5C l.v2x_EDcomp_thick5C (obs=15,470)

I L. L. L. L.

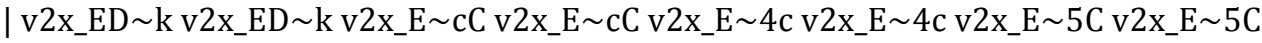

v2x_EDcomp $\sim \mathrm{k}$ |

$--\mid 1.0000$

L1. | 0.98661 .0000

v2x_EDcom $\sim$ cC |

$--. \mid 0.9294 \quad 0.9126 \quad 1.0000$

L1.| $0.9150 \quad 0.9294 \quad 0.9672 \quad 1.0000$

v2x_EDcom $4 \mathrm{c}$ |

\begin{tabular}{l|lllll}
-- & 0.9342 & 0.9185 & 0.9757 & 0.9495 & 1.0000
\end{tabular}

L1.| $0.9192 \quad 0.9344 \quad 0.9469 \quad 0.9759 \quad 0.9707 \quad 1.0000$

v2x_EDcom $\sim 5 \mathrm{C} \mid$

\begin{tabular}{l|lllllll}
-- & 0.9813 & 0.9680 & 0.9217 & 0.9079 & 0.9281 & 0.9139 & 1.0000
\end{tabular}

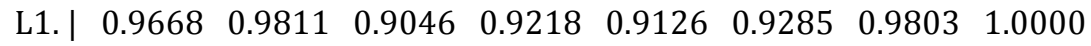

. corr v2x_frassoc_thick l.v2 $\mathrm{x}_{-}$frassoc_thick v2 $\mathrm{x}_{-}$frassoc_thick3cC l.v2 $\mathrm{x}_{-}$frassoc_thick3cC

v2x_frassoc_thick $4 \mathrm{c}$ l.v2 $\mathrm{x}_{-}$frassoc_thick $4 \mathrm{c}$ v2x_frassoc_thick5C l.v2 $\mathrm{x}_{-}$frassoc_thick5C

(obs=15,973)

| L. L. L. L.

| c_thick c_thick v2x_fr.. v2x_fr.. v2x_fr.. v2x_fr.. v2x_fr..v2x_fr..

v2x_frasso $\mathrm{k}$ |

$--\mid 1.0000$

L1. | 0.98601 .0000

v2x_frass $\sim \mathrm{cC}$ |

$\begin{array}{llll}--. & 0.9350 & 0.9182 & 1.0000\end{array}$

L1.| $0.9215 \quad 0.9347 \quad 0.9702 \quad 1.0000$ 


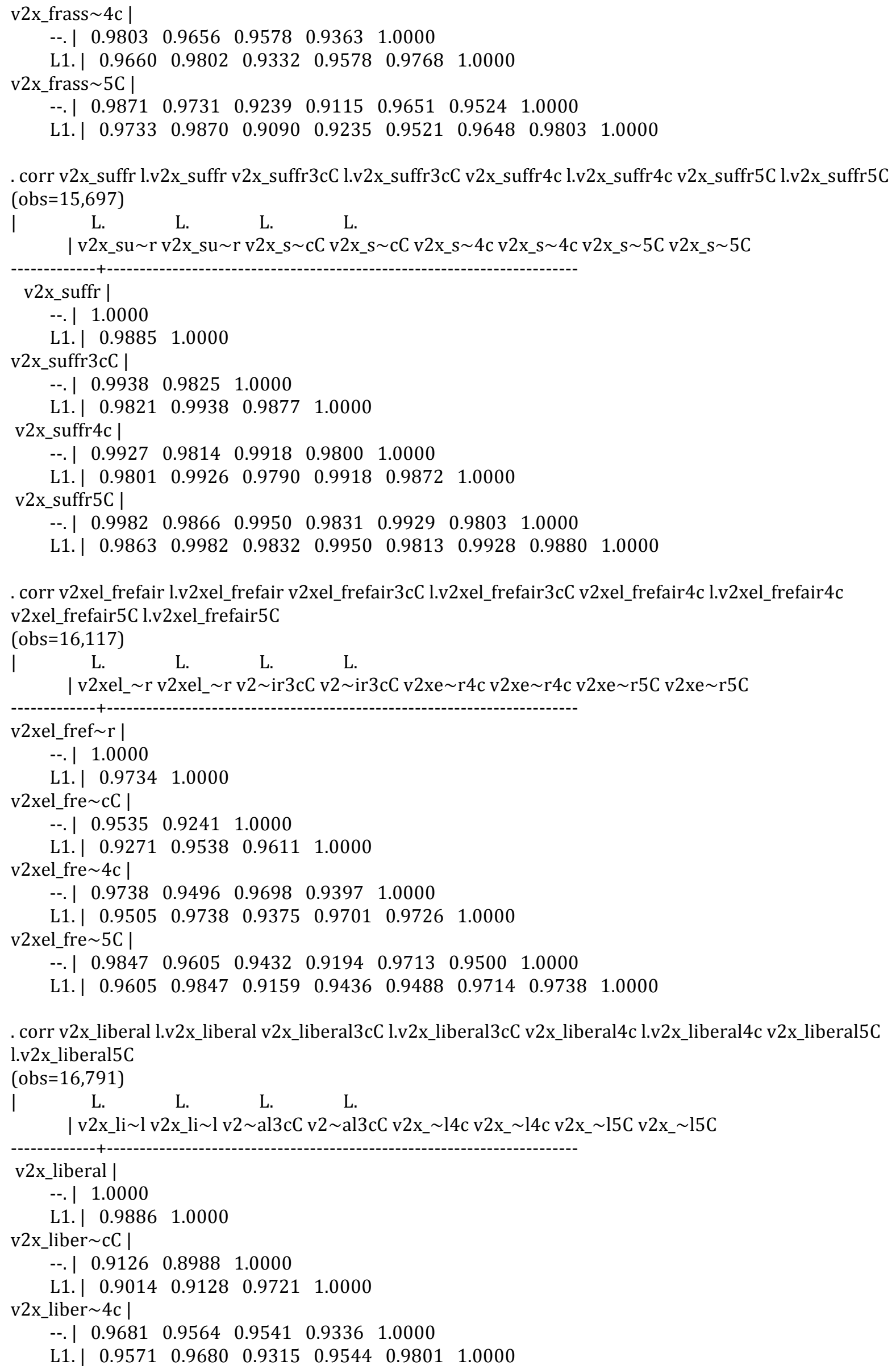


v2x_liber $\sim 5 \mathrm{C}$ |

$\begin{array}{llllllll}-- & 0.9795 & 0.9679 & 0.8875 & 0.8773 & 0.9466 & 0.9365 & 1.0000\end{array}$

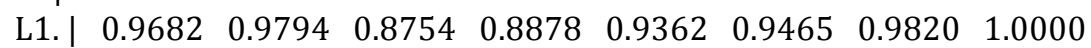

.corr v2xcl_rol l.v2xcl_rol v2xcl_rol3cC l.v2xcl_rol3cC v2xcl_rol4c l.v2xcl_rol4c v2xcl_rol5C l.v2xcl_rol5C (obs=16,326)

|

L. L. L. L.

| v2xcl_ $\sim \mathrm{l}$ v2xcl_ l v2xcl $\sim \mathrm{cC}$ v2xcl $\sim \mathrm{cC}$ v2xcl $\sim 4 \mathrm{c}$ v2xcl $4 \mathrm{c}$ v2xcl $5 \mathrm{C}$ v2xcl $\sim 5 \mathrm{C}$

v2xcl_rol |

$-. \mid 1.0000$

L1.| $0.9911 \quad 1.0000$

v2xcl_rol3cC |

-..| $0.9051 \quad 0.8946 \quad 1.0000$

L1. | $0.89690 .9053 \quad 0.9763 \quad 1.0000$

v2xcl_rol4c|

\begin{tabular}{l|lllll}
-- & 0.9699 & 0.9608 & 0.9471 & 0.9299 & 1.0000
\end{tabular}

L1.| $0.96120 .9698 \quad 0.92790 .9475 \quad 0.9824 \quad 1.0000$

v2xcl_rol5C |

\begin{tabular}{l|lllllll}
$--\mid$ & 0.9808 & 0.9715 & 0.8943 & 0.8867 & 0.9530 & 0.9449 & 1.0000
\end{tabular}

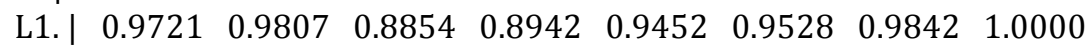

. corr v2x_jucon l.v2x_jucon v2 $x_{-} j u c o n 3 c C$ l.v2x_jucon3cC v2x_jucon4c l.v2x_jucon4c v2 $x_{-} j u c o n 5 C$

l.v2x_jucon5C

(obs=16,143)

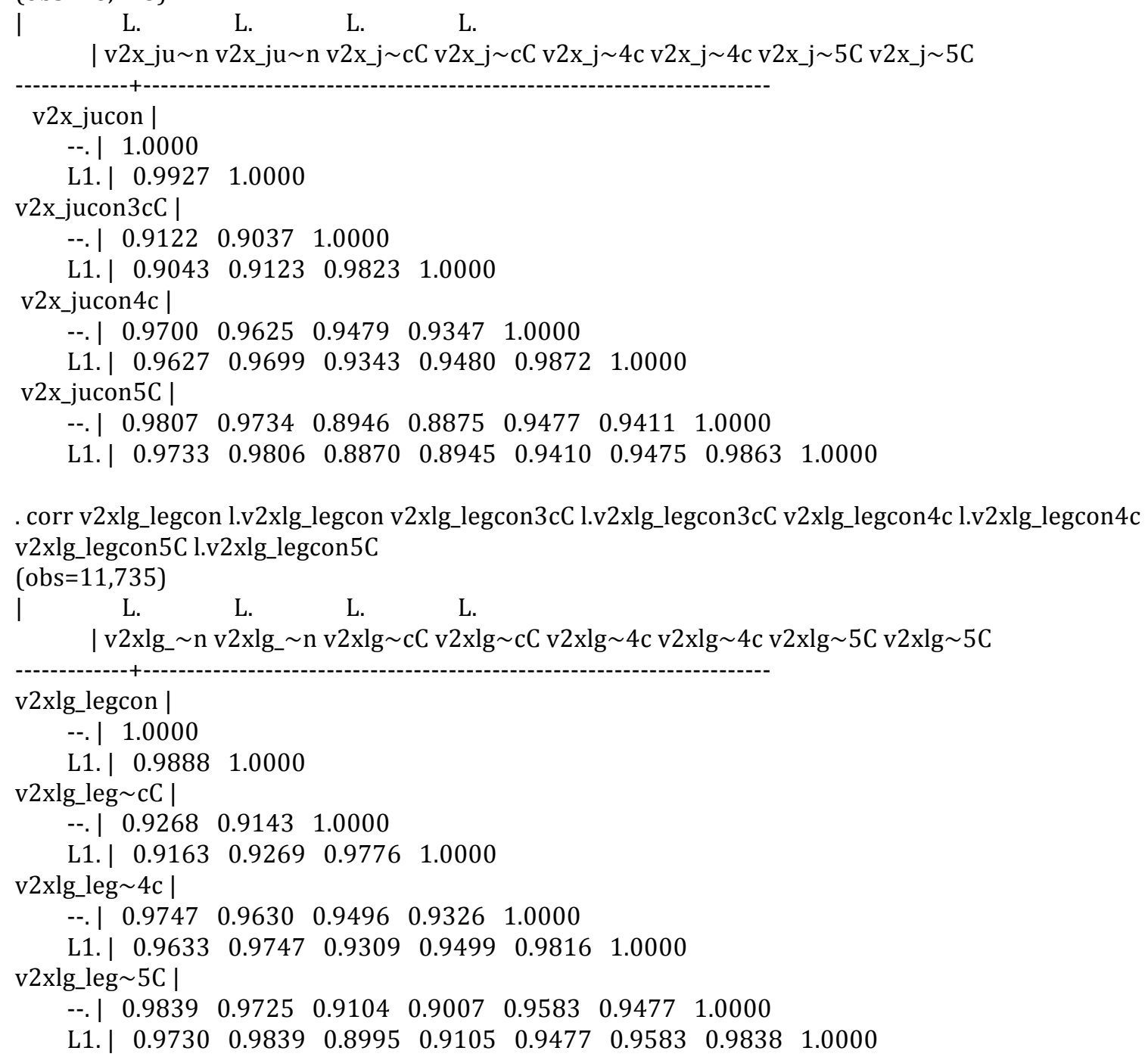


. corr v2xdl_delib l.v2xdl_delib v2xdl_delib3cC l.v2xdl_delib3cC v2xdl_delib4c l.v2xdl_delib4c v2xdl_delib5C l.v2xdl_delib5C

(obs=16,249)

I L. L. L. L.

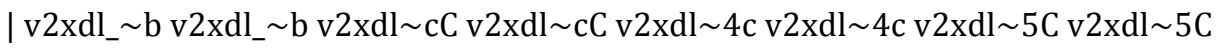

v2xdl_delib |

- -. 1.0000

L1. | 0.98411 .0000

v2xdl_del cC |

\begin{tabular}{l|lll}
-- & 0.9187 & 0.9010 & 1.0000
\end{tabular}

L1. | $0.9036 \quad 0.9188 \quad 0.9683 \quad 1.0000$

v2xdl_del $4 \mathrm{c}$ |

\begin{tabular}{l|lllll}
-- & 0.9725 & 0.9557 & 0.9518 & 0.9278 & 1.0000
\end{tabular}

L1.| $0.95620 .9724 \quad 0.9255 \quad 0.9521 \quad 0.9734 \quad 1.0000$

v2xdl_del $\sim 5 \mathrm{C}$

\begin{tabular}{l|lllllll}
.-- & 0.9823 & 0.9663 & 0.9080 & 0.8940 & 0.9560 & 0.9408 & 1.0000
\end{tabular}

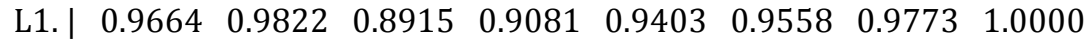

.corr v2x_egal l.v2x_egal v2x_egalC_3c l.v2x_egalC_3c v2x_egalC_4c l.v2x_egalC_4c v2x_egalC_5C l.v2x_egalC_5C

(obs $=16,321$ )

I L. L. L. L.

| v2x_egal v2x_egal v2x_e 3c v2x_e $3 \mathrm{c} v 2 \sim 1 \mathrm{C} \_4 \mathrm{c} v 2 \sim 1 \mathrm{C} \_4 \mathrm{c} v 2 \sim \mathrm{lC} \_5 \mathrm{C}$ v2 lC_5C

v2x_egal |

$--. \mid 1.0000$

L1.| 0.99541 .0000

v2x_egalC_3c |

$\begin{array}{llll}-- & 0.9221 & 0.9158 & 1.0000\end{array}$

L1. | $0.9195 \quad 0.9228 \quad 0.9854 \quad 1.0000$

v2x_egalC_4c |

$\begin{array}{llllll}-. & 0.9734 & 0.9688 & 0.9511 & 0.9424 & 1.0000\end{array}$

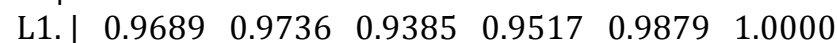

v2x_egalC_5C |

$\begin{array}{lllllllll}-. & 0.9821 & 0.9770 & 0.9116 & 0.9092 & 0.9549 & 0.9508 & 1.0000\end{array}$

$\begin{array}{lllllllll}\text { L1.| } & 0.9778 & 0.9821 & 0.9068 & 0.9123 & 0.9515 & 0.9550 & 0.9894 & 1.0000\end{array}$

.corr v2x_partip l.v2x_partip v2x_partipC_3cC l.v2x_partipC_3cC v2x_partipC_4c l.v2x_partipC_4c v2x_partipC_5C l.v2x_partipC_5C

(obs=19,786)

I L. L. L. L.

| v2x_pa p v2x_pa p v2x _3cC v2 $\sim$ _3cC v2 pC_4c v2 pC_4c v2 pC_5C v2 pC_5C

v2x_partip |

$--. \mid 1.0000$

L1.| $0.9924 \quad 1.0000$

v2x_par _ $3 \mathrm{cC} \mid$

-..| $0.9252 \quad 0.9186 \quad 1.0000$

L1.| $0.9170 \quad 0.9247 \quad 0.9777 \quad 1.0000$

v2x_part _ 4c |

$\begin{array}{llllll}-- & 0.9288 & 0.9226 & 0.9939 & 0.9724 & 1.0000\end{array}$

L1.| $0.9205 \quad 0.92830 .97190 .9938 \quad 0.9787 \quad 1.0000$

v2x_part _ 5C |

$\begin{array}{llllllll}--. \mid & 0.9509 & 0.9437 & 0.8988 & 0.8923 & 0.9033 & 0.8968 & 1.0000\end{array}$

\begin{tabular}{ll|lllllll} 
L1.| & 0.9428 & 0.9506 & 0.8948 & 0.8988 & 0.8996 & 0.9033 & 0.9803 & 1.0000
\end{tabular} 


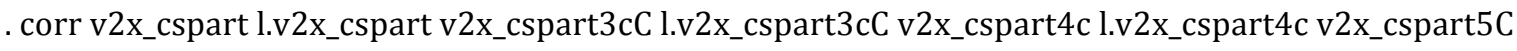
l.v2x_cspart5C

(obs $=16,082$ )

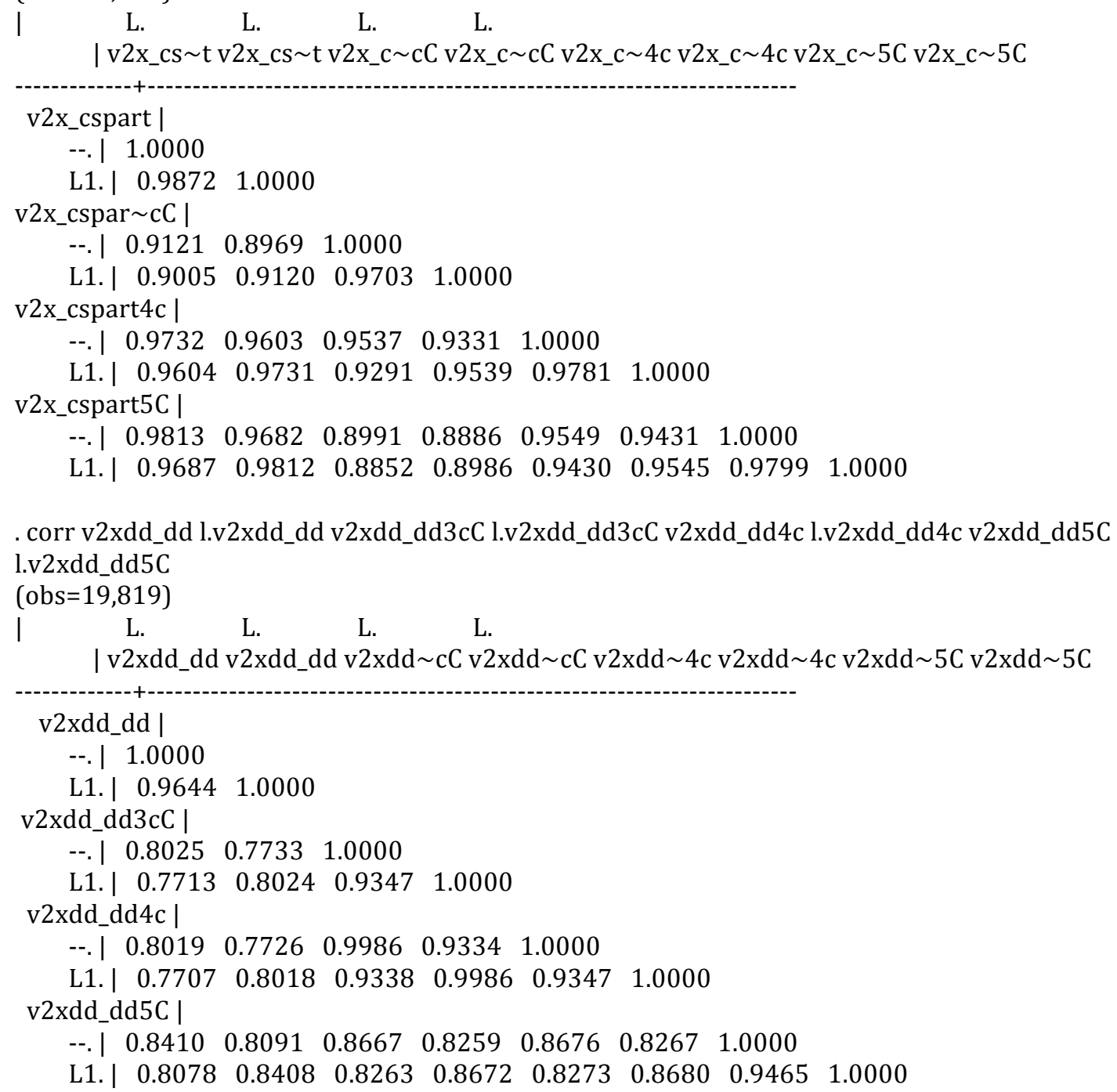

. corr v2xel_locelec l.v2xel_locelec v2xel_locelec3cC l.v2xel_locelec3cC v2xel_locelec4c l.v2xel_locelec4c v2xel_locelec5C l.v2xel_locelec5C

. corr v2xel_regelec l.v2xel_regelec v2xel_regelec3cC l.v2xel_regelec3cC v2xel_regelec4c l.v2xel_regelec4c v2xel_regelec5C l.v2xel_regelec5C 
(obs=15,314)

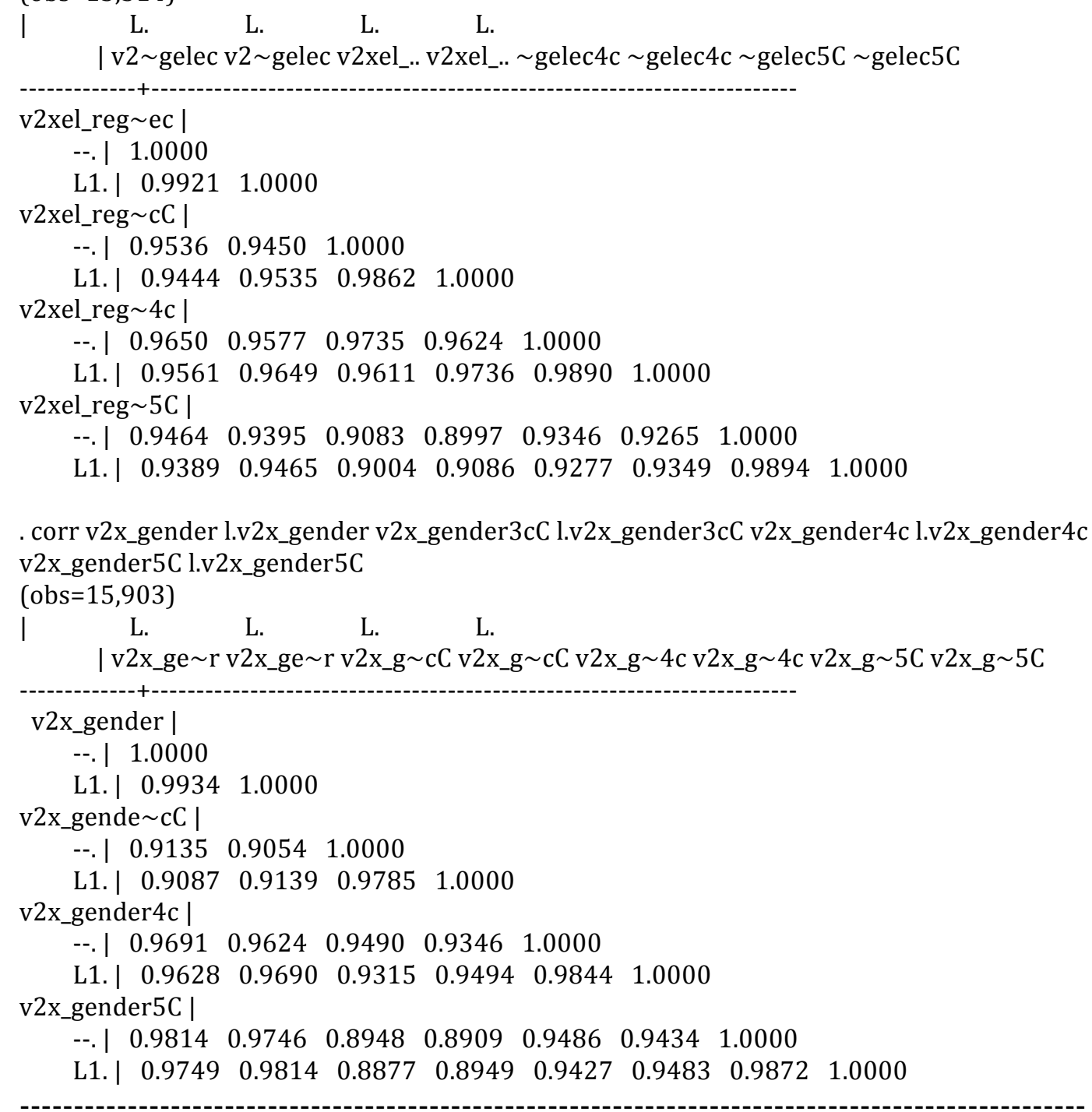

